\title{
Impact of the Renewable Energy Development in Lithuania's Energy Economy
}

\author{
Rita Bužinskiené ${ }^{1}$
}

\begin{abstract}
Paper is characterized by scientific novelty as it involves a very scarce research problem in Lithuanian's energy sector, assessing the impact of renewable energy resources on the energy economy. Renewable energy sources have a multiplier effect in spurring the economy and the development of not only the energy sector but also all the supporting activities related to such industry. The impact of the development of renewable energy is one of the factors that develop the quality of technology innovation development. This study includes the impact of renewable energy on the energy economy, using multiple linear regression models. The results of the study have shown that renewable energy resources: wind, sun, water, geothermal and biomass can not always be used together because they compete with each other and therefore reduce the efficiency of the energy economy. In this context, three combinations of renewable energy resources have been developed, which have been adapted to assess the impact of the energy economy on energy productivity and energy intensity. It has been found that the combination of resources of the second model (M2) RE is significant for the efficiency of the energy economy.
\end{abstract}

Keywords: Renewable energy resources; Energy economy; Impact of efficiency

\section{Introduction}

Lithuania, as in the whole of the European Union (EU), is discussing a strategy for reducing the impact of climate change. Members of the international community agree that reducing greenhouse gas emissions to the atmosphere is necessary to avoid dangerous climate change. The Energy Independence Strategy'2020 reveals that the key priorities include energy security, diversification of energy supply, energy efficiency and integration of Lithuania's energy network with the energy systems of the European Union. It requires each EU Member State to introduce energy efficiency obligation schemes and policy tools to increase the efficiency of energy use in households, industry and the transport sector. These targets to help the EU achieve a more competitive, secure and sustainable energy system and to meet its long-term 2050 greenhouse gas reductions target. According to them, in the long term, it will be necessary to significantly reduce global emissions, in order to avoid dangerous climate change. The EU is committed to 2050 to reduce its emissions by $80-95 \%$ compared to the 1990 level if developed countries work together to bring about similar efforts. The strategy sends a strong signal to the market, encouraging private investment in new pipelines, electricity networks, and low-carbon technology (2030 Energy Strategy; Directive 2012/27/EU, FMEAE 2014; REY 2016, BEM 7; ECR 2017). Renewable energy plays a substantial role in the energy economy and it is the major source for the economic development of any country. The Energy Law of the Republic of Lithuania defines energy as a branch of the state economy, which includes energy activities, including 
energy exploration, extraction, recycling, production, storage, transportation, transmission, distribution, supply, trade, marketing and/or operation of energy facilities and equipment (Law of LR Energy, No. IX-884, 2002). All this shows that energy is one of the important economic objects occupying strategically important areas of activity. The energy sector as an object of research occupies an important position in scientific terms. One of the widest research objects is renewable energy resources. The majority of scientists appreciate the impact of these resources on economic growth in different foreign countries. Research by scientists has revealed these results: 1. Soava and et al. (2018), analyzed the relationship between economic growth and renewable energy consumption, using data for 28 countries of the European Union over the period 19952015. The results of the study showed that renewable energy consumption has a strong positive impact on economic growth. 2. Oguz and Aslan (2013), analyzed the relationship between energy consumption and economic growth for 22 Organisation for Economic Co-operation and Development (OECD) countries over the period 19602005. The results of the study showed that while in most cases there is a strong relationship that starts from economic growth to energy consumption, the strongest relationship from energy consumption to economic growth is shown only for Iceland and Portugal. 3. Maradin et al. (2007), found that renewable energy technologies (RET) have a multiplier effect in spurring the economy and the development of not only the energy sector but also stimulates economic growth. 4. Apergis and Payne (2012), analyzed bidirectional causality between renewable energy consumption and economic growth exists in both the short and long run in the period 1990-2007, 80 OECD countries. 5. Gan and Smith (2011), found, that GDP promotes renewable energy development, whereas R\&D investment, energy prices and CO2 emissions cannot promote (1994-2003, 26 European countries) and others. However, there is a lack of research into the benefits of the development of renewable energy resources for energy economic activity. This paper investigates the energy development from renewable energy sources theoretic framework and uses annual data of $2004-2016$ to measure energy renewable resources development in Lithuanian's energy economy. Assessing the development of renewable resources in the energy economic activity is created energy efficiency model. Processes in the Energy Efficiency Model illustrate the importance of the development of renewable energy sources and the efficiency of the energy sector, which raises a problematic question: what renewable energy resources affect energy economic activity in order to ensure efficiency in the energy sector. How to improve the performance of the energy sector to maximize the energy benefits of developing renewable energies. The energy economy efficiency is measured in economic indicators: energy productivity and energy intensity. The impact of renewable energy resources on the energy economy is determined by using a linear regression model.

The purpose - evaluation of the impact of renewable energy resources on the efficiency of the energy economy.

The research methods used in the paper include the collection of primary and secondary information sources and quantitative data, which are then used for comparative analysis.

\section{The Tendency of Lithuanian's Energy Economy Indicators}


Lithuania's National Energy Strategy has a legally binding target, in the year 2020 , the share of renewable energy would account for at least $23 \%$ of the total final energy consumption of the country, and the share of renewable energy would account for at least 10\% of final energy consumption in the transport sector (ECC 2017). It can be noted that in 2014, 23\% of the total number of people in the EU was reached (Figure 1).

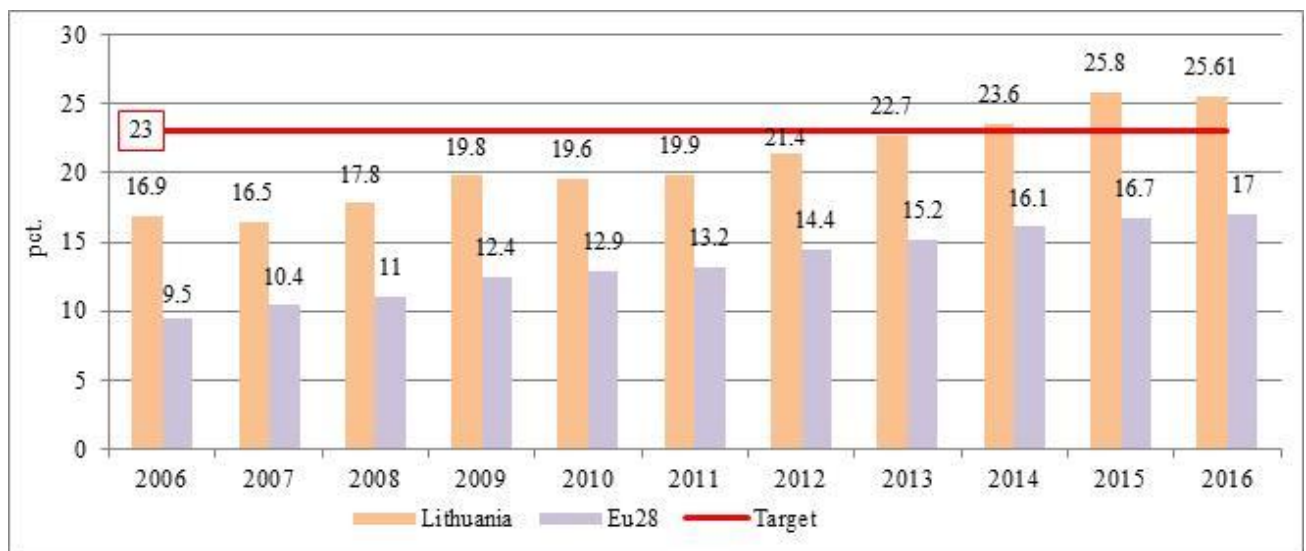

Fig.1. Energy production using renewable energy resources, \% Sources: Eurostat

According to the results, energy production using renewable energy resources growth about 8,71 percentage points (p. p.) in Lithuania during the 10 years. The renewables accounted for 25,61\% of final energy consumption compared to EU 28 members state $17 \%$ in 2016, representing more than $86 \%$ of the 2020 target. In the future, Lithuania's objective is to achieve a $30 \%$ share of renewables in the final energy consumption balance in 2020; a 45\% share of renewables in the final energy consumption balance in 2030; and 80\% share of renewables in the final energy consumption balance in 2050 .

Another indicator is the share of renewable energy in gross final energy consumption by sector. The analysis shows that EU28 members states in the electricity sector, the share of renewable energy the during 2006 - 2016 years went up from 15,4\% to 29,6\%, in the transport sector went up from $2,5 \%$ to $7,1 \%, 7,1 \%$ and in the heating sector in the same period, the share of renewable energy went up from 11,4\% to 19,6\% (Table 1 ).

Table 1. Share of renewable energy in gross final energy consumption by sector, $\%$

\begin{tabular}{|l|c|c|c|c|c|c|}
\hline \multirow{2}{*}{ Indicators } & \multicolumn{3}{|c|}{ Lithuania } & \multicolumn{3}{|c|}{ EU28 } \\
\cline { 2 - 7 } & $\mathbf{2 0 0 6}$ & $\mathbf{2 0 1 1}$ & $\mathbf{2 0 1 6}$ & $\mathbf{2 0 0 6}$ & $\mathbf{2 0 1 1}$ & $\mathbf{2 0 1 6}$ \\
\hline RES-share in the general electricity, \% & 4 & 9 & 16,8 & 15,4 & 19,7 & 29,6 \\
\hline RES-share heating and cooling, $\%$ & 29,2 & 32,8 & 46,5 & 11,4 & 15,6 & 19,6 \\
\hline RES-share in transport, \% & 1,9 & 3,8 & 3,6 & 2,5 & 4 & 7,1 \\
\hline
\end{tabular}

Sources: Eurostat

According to the results, in 2016 the largest increase in renewable energy capacities was in electricity and heating and cooling sectors - in comparison to 2006, respectively it went up by 12,8 p. p and 17,3 p.p. (Lithuania). The smallest increase in renewable energy capacities was in the transport sector - in comparison to 2006, respectively it went up by 1,7 p.p. (Lithuania). Lithuania's results show that RES -share in the heating and cooling sector is higher than the EU 28 member states, respectively, i.e. about 26,9 p.p. (2016). 
In 2050, the objective is Lithuania would have to produce about $70 \%$ of its own heat and electricity, while the share of green energy in transport should reach $50 \%$.

Renewable energy sources are understood as inexhaustible energy resources, they are continually renewed and coming from natural sources: wind, wave, tidal, solar, aerothermal, geothermal, hydrothermal and ocean, hydropower, bioenergy, biomass, biofuel, landfill gas, wastewater treatment gas, and biogas and so on. Here is a list of the main types of practically utilized alternative energy sources (Table 2).

Table 2. Conversion of renewable energy

\begin{tabular}{|l|l|}
\hline Renewable sources of energy & Conversion \\
\hline Wind & Electricity \\
\hline Solar & Heating / cooling, electricity \\
\hline Biomass & Heating / cooling, transport, electricity \\
\hline Water & Electricity \\
\hline Geothermal energy & Heating / cooling, electricity \\
\hline
\end{tabular}

Sources: John 2004; Ma L et al. 2009; Heal 2010; Lund 2010; Law on Renewable Energy, 2011; Miškinis et al. 2014; International Energy Agency 2015; Hagen 2016; Marčiukaitis et al. 2016.

We can see five main types of renewable energy are important for our energy sector: Wind is the motion of air molecules can be harvested in wind turbines that spin the shaft of electric generators or in windmills; Sunlight is the solar photon flux can be converted to heat, electricity or chemical energy; Biomass is organic materials can be used for cooking and heating, as well as to produce electricity and liquid transportation fuels. In the transport sector two types of biofuels are used as fuel from biomass: biodiesel and bioethanol; Water is the potential and kinetic energy of flowing water can be tapped to produce electricity or mechanical tasks; Earth's internal heat (Geothermal energy) can be used for heating and electricity production.

Lithuania's governments aim to increase the efficiency of the energy economy. Two key indicators are used for energy efficiency: energy productivity and energy intensity. The energy intensity does give some indication of how efficiently economies are able to harness primary energy. Improving energy intensity is important as it encourages more energy economic activity and GDP growth. Low energy intensity is desirable as it indicates an effective energy infrastructure. The energy productivity identifies to what extent there is a decoupling between energy consumption and economic growth. It measures the productivity of energy consumption and provides a picture of the degree of decoupling of energy use from growth in GDP (Figure 2) (Štreimikienè et al. 2016). 


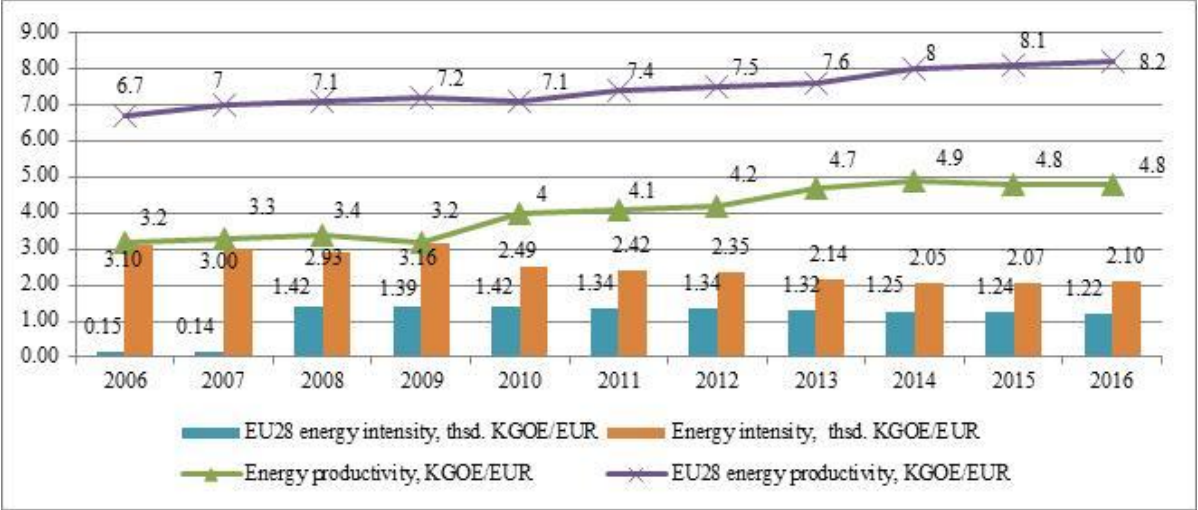

Fig.2. Energy intensity and Energy productivity in Lithuania Sources: Eurostat

According to the results, we can see that Lithuania's' energy intensity decreased 1,0 thsd. TOE/EUR from 2006 till 2016, since entering the EU however economic crisis had a negative impact and energy intensity started to increase (EU28 increased 1,07 thsd. TOE/EUR). The trend of energy intensity decrease can be noticed following the recovery from the economic crisis in 2010. Lithuania's energy productivity was grown up by 1,6 KGOE/EUR (EU28 increased 1,5 KGOE/EUR). These results show that energy productivity increased at the same time when the Gross domestic product (GDP) during 2006-2016 years had risen position in Lithuania $41 \%$. Comparing these indicators between them, we can see, that energy intensity is inversely related to energy productivity; that is the bigger the energy productivity of a given process, the smaller its energy intensity.

As mentioned earlier, there is a lack of research to assess the impact of the development of renewable energy resources on the efficiency of the energy economy. In view of this, an energy efficiency model has been developed.

\section{Methodology}

In this study, the energy efficiency model shown in Figure 3 is selected as a framework and theoretical starting point in understanding the ongoing processes between the energy sector and the development of renewable energy resources, using key energy economy indicators to measure the performance of the energy economy.

The proposed energy efficiency model includes the entire energy economy that reveals how the energy sector provides secure, efficient, environmentally friendly energy production, supply and transfer to consumers. The development of renewable energy resources depends on the ability of the energy sector to invest in new technologies that save energy. Another strategically important aspect of energy is to ensure the need for other industries to consume energy from renewable resources. The main economic indicators of energy productivity and energy intensity illustrate the efficiency of the energy economy. These indicators reveal the effect of the use and development of renewable energy resources, which provides continuous feedback on the efficient growth of the energy sector. 


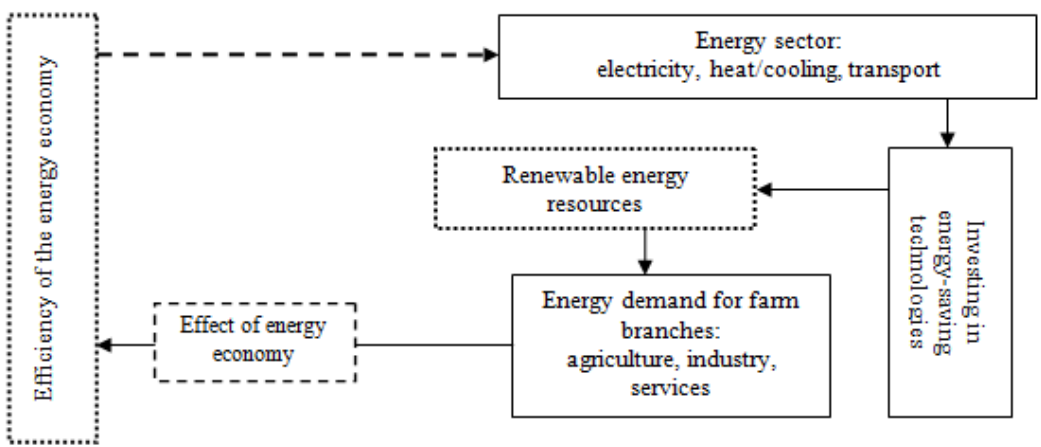

Fig 3. Energy-Efficiency Model, Sources: created by the author

In order to test the energy efficiency model practically, a multi-linear linear regression method is chosen. This method allows you to control many other factors that simultaneously affect a dependent variable. This is important both for verifying the validity of the economic theory and for assessing the effectiveness of ongoing economic activity when the study is based on non-experimental data. Multiple regression provides links between two or more independent variables. The regression analysis model allows predicting variable values from independent variable values (Forsströmet et. al. 2011; Wooldridge, 2010; Čekanavičius and Murauskas 2001).

The standard expression of a multiple linear regression model is:

$$
\mathrm{Y}_{i}=\beta_{0}+\beta_{1} x_{1 i}+\beta_{2} x_{2 i}+\ldots+\beta_{k} x_{k i}+e_{i}
$$

Here: $Y$ - dependent variable; $\beta_{0}, \beta_{1}, \beta_{2}, \ldots, \beta_{k}$ - model coefficients (not known in advance, they are found by the least squares method and by checking the bypothesis about the suitability of the model); $x_{1}, \ldots, x_{k}-$ analyzing factors; $e_{i}$ - accidental error. Multiple regression model assumptions: $e_{i}-$ normal distributed random values; all $\boldsymbol{e}_{i}$ averages are zero, that is $e_{i}=0$; all $\boldsymbol{e}_{i}$ variances are equal to an unknown number $\sigma^{2}$; all $\boldsymbol{e}_{i}$ independent.

In the analysis of the impact of renewable energy resources development on the energy sectors, two economic indicators have been chosen: energy productivity and energy intensity. These indicators point to the level of achievement of the country's energy economy (Table 3).

Table 3. Energy economy indicators

\begin{tabular}{|l|l|}
\hline INDICATORS & DESCRIPTION \\
\hline $\begin{array}{l}\text { Energy } \\
\text { productivity }\end{array}$ & $\begin{array}{l}\text { It is an indicator of the amount of economic output that is derived from each } \\
\text { unit of energy consumed. Economy-wide energy productivity is generally } \\
\text { measured as the national gross domestic product (GDP, in millions of dollars) } \\
\text { divided by petajoules (PJ) of primary energy consumed. }\end{array}$ \\
\hline Energy intensity & $\begin{array}{l}\text { It is a measure of the energy inefficiency of an economy. It is calculated as } \\
\text { units of energy per unit of GDP. Energy intensity is the ratio between gross } \\
\text { inland energy consumption (GIEC) and gross domestic product (GDP), } \\
\text { calculated for a calendar year. }\end{array}$ \\
\hline
\end{tabular}

Although most of these energy indicators measures are not directly connected with the 
renewable energy sector, economic synergies exist between efficiency improvements and renewable energy. Synergies exist between energy intensity and energy productivity can support increased renewable energy deployment. The development of these indicators as a driving force promotes the growth of the country's economy through activities developed by the efficiency of the energy sector activities. Creation of the model for assessment of the impact of renewable energy resources development on the energy economy activities (Table 4).

Table 4. Description of the variables for the analysis of the impact of renewable energies on the energy economy

\begin{tabular}{|l|l|l|}
\hline $\begin{array}{l}\text { NOTATION OF } \\
\text { VARIABLE }\end{array}$ & METHOD OF INDICATOR \\
\hline $\begin{array}{l}\text { *Energy productivity, } \\
\text { KGOE }\end{array}$ & Economic output / Energy used & $\begin{array}{l}\text { Dependent } \\
\text { variable }\end{array}$ \\
\hline $\begin{array}{l}\text { Share of renewable energy } \\
\text { from wind sources, \% }\end{array}$ & $\begin{array}{l}\text { Gross inland consumption of wind, thsd. TOE / } \\
\text { Groms inland consumption of renewable energies, } \\
\text { thsd. TOE x 100\% }\end{array}$ & $\begin{array}{l}\text { Independent } \\
\text { variable }\end{array}$ \\
\hline $\begin{array}{l}\text { Share of renewable energy } \\
\text { from solar sources, \% }\end{array}$ & $\begin{array}{l}\text { Gross inland consumption of solar, thsd. TOE / } \\
\text { Gross inland consumption of renewable energies, } \\
\text { thsd. TOE x 100\% }\end{array}$ & \\
\hline $\begin{array}{l}\text { Share of renewable energy } \\
\text { from hydro sources, \% }\end{array}$ & $\begin{array}{l}\text { Gross inland consumption of hydro, thsd. TOE / } \\
\text { Gross inland consumption of renewable energies, } \\
\text { thsd. TOE x 100\% }\end{array}$ & \\
\hline $\begin{array}{l}\text { Share of renewable energy } \\
\text { from geothermal sources, } \%\end{array}$ & $\begin{array}{l}\text { Gross inland consumption of geothermal, thsd. } \\
\text { TOE / Gross inland consumption of renewable } \\
\text { energies, thsd. TOE x 100\% }\end{array}$ & \\
\hline $\begin{array}{l}\text { Share of renewable energy } \\
\text { from biomass sources, \% }\end{array}$ & $\begin{array}{l}\text { Gross inland consumption of biomass, thsd. TOE } \\
\text { / Gross inland consumption of renewable } \\
\text { energies, thsd. TOE x 100\% }\end{array}$ \\
\hline
\end{tabular}

*Euro per kilogram of oil equivalent (KGOE); ** Kilograms of oil equivalent (KGOE) per thousand euro;

The multi-regression model requires the reliability of the results obtained to be verified, and therefore the reliability of statistical data is used (Table 5).

Table 5. Reliability tests for the regression model

\begin{tabular}{|c|c|c|}
\hline Indicators & Reliability test & Description \\
\hline $\begin{array}{l}\text { Pearson'correlation } \\
\text { coefficient }\end{array}$ & $\begin{array}{l}\text { If }[0,9 ; 1] \text { - very strong correlation; } \\
{[0,7 ; 0,89] \text { - strong correlation; }[0,4 ;} \\
0,69] \text { - medium correlation; }[0.2 ; 0,39] \\
\text { - weak correlation; }[0 ; 0,19] \text { - very } \\
\text { weak correlation }\end{array}$ & $\begin{array}{l}\text { The correlation coefficient is a } \\
\text { criterion for the quantification of } \\
\text { linear dependency between } \\
\text { variables or a measure of the } \\
\text { strength of a relationship. }\end{array}$ \\
\hline $\begin{array}{l}\text { Determination } \\
\text { coefficients } \mathrm{R}^{2}\end{array}$ & $\begin{array}{l}\text { If } \mathrm{R}^{2} \geq 0,20 \text { or adjusted } \mathrm{R}^{2} \geq 0,25, \text { the } \\
\text { model is appropriate }\end{array}$ & $\begin{array}{l}\text { The determination coefficient } \\
\text { acquires values from the interval } \\
{[0,1] \text {. The higher the coefficient }} \\
\text { value, the better the data model. }\end{array}$ \\
\hline ANOVA p-value & $\begin{array}{l}\text { If } p<0,05 \text { or } \mathrm{df}>0 \text {, the model is } \\
\text { appropriate }\end{array}$ & $\begin{array}{l}\text { It shows whether the model has } \\
\text { a regressor associated with the }\end{array}$ \\
\hline
\end{tabular}




\begin{tabular}{|c|c|c|}
\hline Indicators & Reliability test & Description \\
\hline & & dependent variable. \\
\hline \begin{tabular}{|lr}
\multicolumn{3}{l}{ Multicolinearum } \\
(Value of & Variance \\
Inflation & Factor \\
$($ VIF $))$ &
\end{tabular} & $\begin{array}{l}\text { If VIF }>4 \text { or tolerance }<0,25 \text { the } \\
\text { problem of multicolinearity } . \\
\text { Variable Tolerance }=1 / \mathrm{VIF} \text {. }\end{array}$ & $\begin{array}{l}\text { Shows the correlation of } \\
\text { independent variables included in } \\
\text { the model, do they not correlate } \\
\text { with each other. The dependency } \\
\text { is only related to the dependent } \\
\text { variable. }\end{array}$ \\
\hline $\begin{array}{l}\text { Autocorrelation } \\
\text { (Durbin-Watson } \\
(\mathrm{DW}) \text { test) }\end{array}$ & $\begin{array}{l}\text { If p-value }>0,05 \text {, it is correlation is } \\
\text { not statistically significant (no } \\
\text { autocorrelation). It may vary from } 0 \text { to } \\
\text { 4. The closer } 2 \text {, the less likely it is that } \\
\text { there is autocorrelation between } \\
\text { residual errors. }\end{array}$ & $\begin{array}{l}\text { Checking for a dependent } \\
\text { variable } Y \text { during the period } t \\
\text { does not correlate with error } \mathrm{t}-1 \\
\text { in the period. }\end{array}$ \\
\hline
\end{tabular}

The correlation coefficient itself is simply a way to describe how two variables vary together, so it can be computed and interpreted for any two variables. Correlation computes the value of the Pearson correlation coefficient. Its value ranges from -1 to +1 . The determination coefficient can be interpreted as the ratio of the part of the variance explained by the regression model to the whole dispersion. The value of the determination coefficient must be bigger than 0,20 , and the value of the corrected determination factor (Adjusted $\mathrm{R}$ square) must be bigger than 0,25 , then the regression model is considered appropriate. Anova p-value indicates the evaluation of a variable communication model. If this value is less than 0,05 , this confirms the suitability of the model. When verifying that the independent variables are not multicolored, whether there is a strong correlation between them, the variance inflation factor (VIF) is calculated. When there is a strong correlation between the variables, there is a problem with the so-called multicollinearity. Such multipolarity means that in the regression model, leaving the variable and the variables with which it correlates, there may be a problem of forecast stability. Multipolarity is checked by the value of VIF statistics: if VIF> 4, then independent variables in the model correlate. Instead of using VIF, it is possible to use the indicator - tolerance. There are several tests to check the correlation of errors (Autocorrelation). One of them is Durbin-Watson's (DW) test. Autocorrelation means that model errors are related to each other. Durbin - Watson criteria statistics vary from 0 to 4 . The absence of correlation means that the size of DW statistics is close to 2 . If $\mathrm{DW}$ is close to 0 or 4 , it can be said that $e_{i}$ and $e_{i-1}$ high enough correlation.

\section{Empirical Results}

At the initial stage of the analysis of the impact of renewable energy sources on the energy economy, the correlation between the variables has been established, there was a problem with multicollinearity because the dispersion reduction factor was bigger than 4 (VIF > 4). In this situation, the regression model created cannot be realized to support the conclusions. There are several ways to solve multicollinearity problems: 1 . Removal of one or more strongly correlated factors if they overlap each other, it describes the same characteristics of the analyzed factor; 2. Inclusion of additional data (an increase of the sample); 3. Data 
Correction: Multiple Linear Multiple V ariables Used.

In this study will use first ways to solve multicollinearity problems (Table 6).

Table 6. The problem of multicolinearity

\begin{tabular}{|c|c|c|c|c|c|}
\hline Renewable sources & Wind & Solar & Hydro & Geothermal & Biomass \\
\hline Wind & $x$ & $\mathrm{~V}$ & $\mathrm{~V}$ & $\mathrm{~V}$ & \\
\hline Solar & $\mathrm{V}$ & $x$ & $\mathrm{~V}$ & & \\
\hline Hydro & $\mathrm{V}$ & $\mathrm{V}$ & $\bar{x}$ & $\mathrm{~V}$ & $\mathrm{~V}$ \\
\hline Geothermal & $\mathrm{V}$ & & $\mathrm{V}$ & $x$ & $\mathrm{~V}$ \\
\hline Biomass & & & $\mathrm{V}$ & $\mathrm{V}$ & $\bar{x}$ \\
\hline \multicolumn{6}{|c|}{ Results of multicolinearity } \\
\hline Wind & \multicolumn{3}{|c|}{$=$ (solar, hydro, geothermal) } & \multicolumn{2}{|l|}{$\neq$ (biomass) } \\
\hline Solar & \multicolumn{3}{|c|}{$=$ (wind, hydro) } & \multicolumn{2}{|c|}{$\neq$ (geothermal, biomass) } \\
\hline Hydro & \multicolumn{3}{|c|}{$=$ (wind, solar, geothermal, biomass) } & \multicolumn{2}{|l|}{ 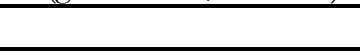 } \\
\hline Geothermal & \multicolumn{3}{|c|}{$=$ (wind, hydro, biomass) } & \multicolumn{2}{|l|}{$\neq$ (solar) } \\
\hline Biomass & \multicolumn{3}{|c|}{$=$ (hydro, geothermal) } & \multicolumn{2}{|l|}{$\neq$ (wind, solar) } \\
\hline
\end{tabular}

$\mathrm{V}$ - it means no multicollinearity problem; empty field means multicollinearity problem.

Table 6 shows four restrictions of this study: 1. Wind correlates with biomass; 2. Solar correlates with geothermal and biomass; 3. Geothermal correlates with solar; 4. Biomass correlates with wind and solar. It can be noticed that only hydro consumption does not correlate with other renewable energy resources. In view of these constraints, there are three combinations of renewable energy resources:1. $Y_{1}=f$ (bydro, biomass, geothermal; 2. $Y_{2}=f$ (bydro, wind, solar); 3. $Y_{3}=f$ (bydro, geothermal, wind). Three models (M1, M2, M3) have been realized when analyzing the effect of composite combinations $\left(Y_{1}, Y_{2}, Y_{3}\right)$ on energy productivity value (Table 7 ). The question posed by the study can be answered: What is the effect of the value of the combinations $\left(Y_{1}, Y_{2}, Y_{3}\right)$ on energy productivity? What $\left(Y_{1}, Y_{2}, Y_{3}\right)$ combinations are best for energy productivity growth?

Table 7. Empirical results of energy productivity

\begin{tabular}{|c|c|c|c|c|c|c|c|c|}
\hline \multirow[t]{2}{*}{ Model } & \multirow{2}{*}{$\begin{array}{c}\text { Dependent } \\
\text { variables }\end{array}$} & \multirow{2}{*}{$\begin{array}{l}\text { Independent } \\
\text { variables }\end{array}$} & \multirow{2}{*}{$\begin{array}{l}\text { Pearson' } \\
\text { correlation } \\
\text { coefficient }\end{array}$} & \multirow{2}{*}{$\begin{array}{c}\mathbf{R} \\
\text { Square }\end{array}$} & \multirow{2}{*}{$\begin{array}{c}\text { Adjusted R } \\
\text { Square }\end{array}$} & \multirow{2}{*}{$\begin{array}{l}\text { Durbin- } \\
\text { Watson } \\
\text { (DW) }\end{array}$} & \multicolumn{2}{|c|}{$\begin{array}{c}\text { Collinearity } \\
\text { Statistics }\end{array}$} \\
\hline & & & & & & & Tolerance & \begin{tabular}{|l|} 
VIF \\
\end{tabular} \\
\hline \multirow{3}{*}{1} & \multirow{11}{*}{$\begin{array}{c}\text { Energy } \\
\text { Productivity }\end{array}$} & Hydro & \multirow{3}{*}{.948} & \multirow{3}{*}{.898} & \multirow{3}{*}{.864} & \multirow{3}{*}{1.604} & .691 & \begin{tabular}{|l|}
1.448 \\
\end{tabular} \\
\hline & & Biomass & & & & & .719 & 1.390 \\
\hline & & Geothermal & & & & & .526 & 1.902 \\
\hline & & & & & & & & \\
\hline \multirow{3}{*}{2} & & Hydro & \multirow{3}{*}{.950} & \multirow{3}{*}{.903} & \multirow{3}{*}{.871} & \multirow{3}{*}{1.508} & .359 & 2.785 \\
\hline & & Wind & & & & & .316 & 3.165 \\
\hline & & Solar & & & & & .373 & 2.680 \\
\hline & & & & & & & & \\
\hline \multirow{3}{*}{3} & & Hydro & \multirow{3}{*}{.943} & \multirow{3}{*}{.889} & \multirow{3}{*}{.853} & \multirow{3}{*}{1.656} & .473 & \begin{tabular}{|l|}
2.113 \\
\end{tabular} \\
\hline & & Geothermal & & & & & .696 & 1.438 \\
\hline & & Wind & & & & & .380 & \begin{tabular}{|l|l|}
2.634 \\
\end{tabular} \\
\hline
\end{tabular}

Based on the data in Table 7, the correlation coefficient between the first model (M1 = 0,948), the second model (M2 =0,950), the third model $(\mathrm{M} 3=0,943)$ and the energy 
productivity level show a very strong positive relationship. The corrected determination coefficient for the first model $(\mathrm{M} 1=R 2=0,864)$, the second model $(\mathrm{M} 2=R 2=0,871)$ and the third model (M3 $=R 2=0,853)$ show that the variables included in the model explain respectively: $86,4 \%, 87,1 \%, 85,3 \%$ energy productivity indicator spread. This accounts for more than 25 percent. This means that the model is suitable for data. Empirically tested models (M1, M2, M3) have no multicolinearity (VIF <4) and autocorrelation (DW test $\mathrm{p}>0.05)$. The three models implemented meet all the requirements and can be used to formulate the conclusions of the study. The following is a dispersal analysis (ANOVA) (Table 8).

Table 8. Disperse analysis (Anova)

\begin{tabular}{|c|c|c|c|c|c|}
\hline Model & Sum of Squares & df & Mean Square & $\mathbf{F}$ & Sig. \\
\hline Regression & 6.693 & 3 & 2.231 & 26.439 & $.000^{\mathrm{a}}$ \\
\hline$1 \longdiv { \text { Residual } }$ & .759 & 9 & .084 & & \\
\hline Total & 7.452 & 12 & & & \\
\hline Regression & 6.731 & 3 & 2.244 & 27.986 & $.000^{\mathrm{a}}$ \\
\hline$2 \longdiv { \text { Residual } }$ & .722 & 9 & .080 & & \\
\hline Total & 7.452 & 12 & & & \\
\hline & & & & & \\
\hline Regression & 6.628 & 3 & 2.209 & 24.128 & $.000^{\mathrm{a}}$ \\
\hline 3 Residual & .824 & 9 & .092 & & \\
\hline Total & 7.452 & 12 & & & \\
\hline
\end{tabular}

Based on Table $8, \mathrm{~F}$ statistics and significance are interpreted. Fkrit. $(3,9)$ and this statistic is significant because $p<0,05$. It can be said that all three of the regression models that have been created are aligned and chosen correctly.

Table 9. Summary of energy productivity results

\begin{tabular}{|c|c|c|c|c|c|c|}
\hline \multirow[t]{2}{*}{ Model } & \multirow{2}{*}{\begin{tabular}{|c}
$\begin{array}{c}\text { Unstandardized } \\
\text { Coefficients }\end{array}$ \\
B
\end{tabular}} & \multirow{2}{*}{$\begin{array}{c}\begin{array}{c}\text { Standardized } \\
\text { Coefficients }\end{array} \\
\text { Beta }\end{array}$} & \multirow[t]{2}{*}{$\mathrm{t}$} & \multirow[t]{2}{*}{ Sig. } & \multicolumn{2}{|c|}{$\begin{array}{l}95.0 \% \text { Confidence } \\
\text { Interval }\end{array}$} \\
\hline & & & & & Lower Bound & Upper Bound \\
\hline (Constant) & 34.699 & & 7.360 & .000 & 24.035 & 45.364 \\
\hline Geothermal & -.815 & -.135 & -1.058 & .318 & -2.559 & .928 \\
\hline Biomass & -.317 & -.750 & -5.974 & .000 & -.437 & -.197 \\
\hline Hydro & -.263 & -.236 & -1.607 & .143 & -.633 & .107 \\
\hline & & & & & & \\
\hline (Constant) & 2.838 & & 3.678 & .005 & 1.093 & 4.583 \\
\hline Wind & .281 & .785 & 4.536 & .001 & .141 & .422 \\
\hline Solar & 1.027 & .260 & 1.408 & .193 & -.624 & 2.678 \\
\hline Hydro & .073 & .065 & .385 & .709 & -.355 & .501 \\
\hline (Constant) & 3.189 & & 4.194 & .002 & 1.469 & 4.909 \\
\hline${ }_{3}$ Wind & .327 & .914 & 5.672 & .000 & .197 & .458 \\
\hline Geothermal & -.627 & -.104 & -.784 & .453 & -2.437 & 1.183 \\
\hline Hydro & .020 & .018 & .099 & .924 & -.434 & .473 \\
\hline
\end{tabular}

The results in Table 9 showed that the expressions of all three models have a significant effect on the value of energy productivity, but this effect is manifested in different directions. Combination of the first model (M1) growth of $1 \%$ reduce the value of 
energy productivity, respectively: Geothermal 0,815\%, Biomass 0,317 \%, Hydro 0,263 $\%$. Combination of the second model (M2) growth of $1 \%$ increase the value of energy productivity, respectively: Wind 0,281\%, Solar 1,03\%, Hydro 0,073\%. Combination of the third model (M3) growth of $1 \%$ increase energy productivity, respectively: Wind $0,327 \%$ and Hydro $0,20 \%$, but Geothermal decreased energy productivity by $0,627 \%$

The results showed, that the impact of all models on energy productivity can vary: M1 model: Geothermal \pm 1,63\%, Biomass \pm 0,63\%, Hydro 0,53\%; M2: Wind \pm 0,28 \%, Solar 2,05\%, Hydro 0,15\%; M3 model: Wind \pm 0,26 \%, Geothermal \pm 1,25\%, Hydro $0,04 \%$ at 95 percent of the probability.

Three models (M1, M2, M3) have been realized when analyzing the effect of composite combinations $\left(Y_{1}, Y_{2}, Y_{3}\right)$ on energy intensity value (Table 7$)$. The question posed by the study can be answered: What is the effect of the value of the combinations $\left(Y_{1}, Y_{2}, Y_{3}\right)$ on energy intensity? What $\left(Y_{1}, Y_{2}, Y_{3}\right)$ combinations are best for energy intensity growth?

Table 10. Empirical results of energy intensity

\begin{tabular}{|c|c|c|c|c|c|c|c|c|}
\hline \multirow{2}{*}{ Model } & \multirow{2}{*}{$\begin{array}{l}\text { Dependent } \\
\text { variables }\end{array}$} & \multirow{2}{*}{$\begin{array}{l}\text { Independent } \\
\text { variables }\end{array}$} & \multirow{2}{*}{$\begin{array}{c}\text { Pearson' } \\
\text { correlation } \\
\text { coefficient }\end{array}$} & \multirow{2}{*}{$\begin{array}{c}\mathbf{R} \\
\text { Square }\end{array}$} & \multirow{2}{*}{$\begin{array}{c}\text { Adjusted R } \\
\text { Square }\end{array}$} & \multirow{2}{*}{$\begin{array}{c}\text { Durbin- } \\
\text { Watson } \\
\text { (DW) }\end{array}$} & \multicolumn{2}{|c|}{$\begin{array}{l}\text { Collinearity } \\
\text { Statistics }\end{array}$} \\
\hline & & & & & & & Tolerance & VIF \\
\hline \multirow{3}{*}{1} & \multirow{11}{*}{$\begin{array}{l}\text { Energy } \\
\text { Intensity }\end{array}$} & Hydro & \multirow{4}{*}{.907} & \multirow{3}{*}{.822} & \multirow{3}{*}{.763} & \multirow{3}{*}{1.259} & .691 & 1.448 \\
\hline & & Biomass & & & & & .719 & 1.390 \\
\hline & & Geothermal & & & & & .526 & 1.902 \\
\hline & & & & & & & & \\
\hline \multirow{3}{*}{2} & & Hydro & \multirow{3}{*}{.902 } & \multirow{3}{*}{.814} & \multirow{3}{*}{.752} & \multirow{3}{*}{1.372} & .359 & 2.785 \\
\hline & & Wind & & & & & .316 & 3.165 \\
\hline & & Solar & & & & & .373 & 2.680 \\
\hline & & & & & & & & \\
\hline \multirow{3}{*}{3} & & Hydro & \multirow{3}{*}{.906} & \multirow{3}{*}{.820} & \multirow{3}{*}{.760} & \multirow{3}{*}{1.346} & .473 & 2.113 \\
\hline & & Geothermal & & & & & .696 & 1.438 \\
\hline & & Wind & & & & & .380 & 2.634 \\
\hline
\end{tabular}

Based on the data in Table 10, the correlation coefficient between the first model (M1 = 0,907), the second model (M2 =0,902), the third model (M3 = 0,906) and the energy productivity level show a very strong positive relationship. The corrected determination coefficient for the first model $(\mathrm{M} 1=R 2=0,763)$, the second model $(\mathrm{M} 2=R 2=0,752)$ and the third model $(\mathrm{M} 3=R 2=0,760)$ show that the variables included in the model explain respectively: $76,3 \%, 75,2 \%, 76,0 \%$ energy intensity indicator spread. This accounts for more than 25 percent. This means that the model is suitable for data. Empirically tested models (M1, M2, M3) have no multicolinearity (VIF <4) and autocorrelation (DW test $\mathrm{p}>0.05$ ). The three models implemented meet all the requirements and can be used to formulate the conclusions of the study. The following is a dispersal analysis (ANOVA) (Table 11).

Table 11. Disperse analysis (Anova)

\begin{tabular}{|l|l|c|c|c|c|c|}
\hline \multicolumn{1}{|l|}{ Model } & Sum of Squares & df & Mean Square & F & Sig. \\
\hline \multirow{2}{|l|}{1} & Regression & 32941.795 & 3 & 10980.598 & 13.890 & $.001^{\mathrm{a}}$ \\
\cline { 2 - 6 } & Residual & 7115.080 & 9 & 790.564 & & \\
\cline { 2 - 7 } & Total & 40056.875 & 12 & & & \\
\hline
\end{tabular}




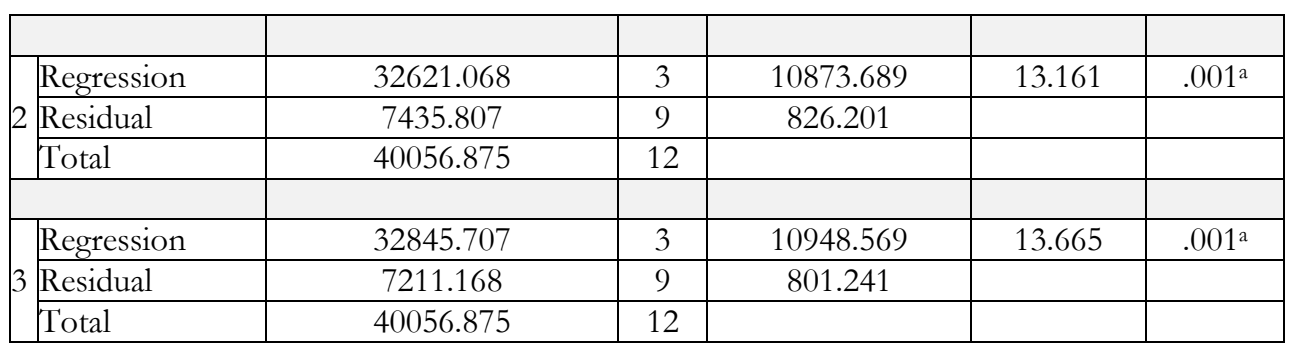

Based on Table 11, F statistics and significance are interpreted. Fkrit. (3,9) and this statistic is significant because $p<0,05$. It can be said that all three of the regression models that have been created are aligned and chosen correctly.

Table 12. Summary of energy intensity results

\begin{tabular}{|l|c|c|c|c|c|c|}
\hline \multirow{2}{*}{ Model } & $\begin{array}{c}\text { Unstandardized } \\
\text { Coefficients }\end{array}$ & $\begin{array}{c}\text { Standardized } \\
\text { Coefficients }\end{array}$ & \multirow{2}{*}{$\mathbf{t}$} & \multirow{2}{*}{ Sig. } & \multicolumn{2}{|c|}{$\mathbf{9 5 . 0 \%}$ Confidence Interval } \\
\cline { 2 - 3 } & $\mathbf{B}$ & $\mathbf{B e t a}$ & & & Lower Bound & Upper Bound \\
\hline (Constant) & -1896.668 & & -4.156 & .002 & -2928.926 & -864.410 \\
\hline Geothermal & 59.476 & .135 & .797 & .446 & -109.283 & 228.236 \\
\hline Biomass & 22.330 & .721 & 4.351 & .002 & 10.720 & 33.940 \\
\hline Hydro & 17.814 & .218 & 1.125 & .290 & -18.003 & 53.631 \\
\hline & & & & & & \\
\hline
\end{tabular}

The results in Table 12 showed that the expressions of all three models have a significant effect on the value of energy intensity, but this effect is manifested in different directions. Combination of the first model (M1) growth of $1 \%$ increase the value of energy intensity, respectively: Geothermal 59,5\%, Biomass 22,3\%, Hydro 17,8 \%. Combination of the second model (M2) growth of $1 \%$ reduce the value of energy intensity, respectively: Wind 22,1\%, Solar 23,5 \%, Hydro 0,138 \%. Combination of the third model (M3) growth of $1 \%$ reduce energy productivity, respectively: Wind 23,3\% and Hydro 2,5 \%, but Geothermal increase energy intensity by 46,4 \%.

The results showed, that the impact of all models on energy productivity can vary: M1 model: Geothermal $\pm 118,95 \%$, Biomass \pm 23,22\%, Hydro 35,63 \%; M2: Wind \pm $44,11 \%$, Solar $\pm 92,75 \%$, Hydro 0,28 \%; M3 model: Wind \pm 46,53 \%, Geothermal \pm $92,75 \%$, Hydro $5,06 \%$ at 95 percent of the probability.

Comparing the results of the study, it can be seen that the combination of RE resources created by the M2 model is one of the best ways to increase the efficiency of the energy economy (Table 13). 
Table 13. Summary of regression analysis results

\begin{tabular}{|c|c|c|c|}
\hline Model & Energy Productivity & Energy Intensity & Findings \\
\hline M1 & Decrease $(-)$ & Increase $(+)$ & unsuitable \\
\hline M2 & Increase $(+)$ & Decrease $(-)$ & suitable \\
\hline M3 & $\begin{array}{l}\text { Increase }(+) \\
\text { Decrease }(-)\end{array}$ & $\begin{array}{l}\text { Increase }(+) \\
\text { Decrease }(-)\end{array}$ & partly suitable \\
\hline
\end{tabular}

The combination of the M2 model has been identified as a significant combination of renewable energy (RE) resources, having the highest and most direct impact on energy efficiency and energy intensity. Using the RE combination of the Model 2, energy productivity increased and energy intensity reduced. This means that a lower value of energy intensity and a higher value for energy productivity increase the efficiency of the energy economy. The combination of the M1 model is not appropriate because the combination of RE resources in this model reduced energy productivity and increased energy intensity. This means that this combination of RE resources for the energy economy is not beneficial. The combination of the M3 model is only partially appropriate, as each RE resource has a different impact on energy productivity and energy intensity indicators, and therefore cannot deliver more efficient performance than the M2 model.

\section{Discussion}

It can be noted that the identified combinations are most suitable for electricity because these resources can be easily converted to electricity. For the heating/cooling sector, these combinations are not suitable because solar, geothermal and biomass cannot be used together. These resources correlate with each other, which reduces the energy economy efficiency. In order to determine which of these resources the best to choose for the efficient operation of the energy sector, it is necessary to carry out additional studies that are not dealt with in this article. In fact, biomass resources are used only in the transport sector. This resource includes the potential for the use of various local resources: straw, wood, waste, etc. However, this study also does not study which of the local resources is the most suitable for use in the transport sector and further research should be carried out.

\section{Conclusions}

To sum up, renewable energy resources are the key to green energy, which occupies an important position in the energy economy. It is a promising energy sector where this sector plays an important role: electricity, heat/cooling, and transport. The development of this area in Lithuania should receive much more attention. The analysis of the development of Lithuanian renewable energy resources revealed that the production of energy using RE resources is increasing every year and has exceeded the established EU28 average. From 2014 Lithuania has achieved its target (energy production from RE resources by $23 \%$ by 2020 ) and this figure was $23,6 \%$. Two indicators were selected for energy efficiency: energy productivity and energy intensity. In Lithuania, energy productivity, compared to EU28, was less than 3,4 KGOE/EUR. All this shows that the 
demand for energy resources has increased due to the inefficient use of energy resources in production processes. In Lithuania, the energy intensity compared to the EU28 countries was 0,88 thsd. KGOE/EUR is lower, this is a positive trend as much less energy is consumed in the production of one product than the EU28 average.

Initial research showed that RE resources cannot use available at the same time, because they compete with each other: Wind with biomass; Solar with geothermal and biomass; Geothermal with solar; Biomass with wind and solar. Only hydro can be used with other resources. Against this background, three renewable energy (RE) resource combinations have been developed to assess the impact on the efficiency of the energy economy performance. For this study used two indicators energy productivity and energy intensity. The study has shown that the combination of the model M2 RE resources is one of the most appropriate choices. Model M2 has a positive impact on the efficiency of the energy economy because it increased energy productivity and reduced energy intensity. This means that a lower value of energy intensity and a higher value of energy productivity can ensure to grow up the efficiency of the energy economy. Using the model M1 RE resource combination was determinate, that this model has a negative effect and it is not beneficial to the energy economy. The combination of the model M3 RE resources is only partially appropriate, because it has different effects on energy productivity and energy intensity indicators, and therefore cannot ensure the growth of energy economy performance.

\section{References}

Apergis, N. and Payne, J.E. 2012. Renewable and non-renewable energy consumption-growth nexus: evidence from a panel error correction model. Energy Economics, Vol. 34, No. 3, 733-738

BEM (Baltic Energy Market). Interconnection Plan GRIP 2017. https://www. entsog. eu/public /uploads/ files/ publications/GRIPs/2017/entsog_BEMIP_GRIP_2017_Main_web_s.pdf

Čekanavičius, V., Murauskas, G. 2001. Statistika ir jos taikymai I. Vilnius: TEV. bttp://stat.vadoveliai lt/files/ STAT1SV_DEMO.pdf

Directive 2012/27/EU of the European Parliament and of the Council of 25 October 2012http://eurlex.europa.eu/ LexUriServ /Lex Uri Serv.do?uri =OJ:L:2012: 315: 0001 : 0056:EN:PDF

ECC (European Commission. Communication from the commission to the european parliament, the council, the european economic and social committee, the committee of the regions and the european investment bank), Third Report on the State of the Energy Union, 2017. https://ec.europa.eu/commission/sites/beta-political/files/annex-3-progress-national-energyclimate-plans_en.pdf

ECR (European Commission. Communication from the commission to the European parliament, the council, the European economic and social committee, the committee of the regions and the European investment bank, Third Report on the State of the Energy Union). 2017. https://ec.europa.eu/commission/sites/beta-political/files/annex-3-progress-national-energyclimate-plans_en.pdf

Energy Strategy 2030. https://ec.europa.eu/energy/en/topics/energy-strategy-and-energy-union/2030energy-strategy

FMEAE (The Federal Ministry for Economic Affairs and Energy). 2014. Renewable Energy Sources in Figures. https://www.erneuerbare-energien.de/EE/Redaktion/DE/Downloads/renewableenergy-sources-in-figures-2014.pdf?_blob=publicationFile\&v $=3$

Forsström, J., Lahti, P., Pursiheimo, E., Rämä, M., Shemeikka, J., Sipilä, K., Tuominen, P., Wahlgren, I. 2011. Measuring energy efficiency. VTT TIEDOTTEITA - RESEARCH NOTES 2581. ISSN 1455-0865 https://www.vtt.fi/inf/pdf/tiedotteet/2011/T2581.pdf

Gan, J.B. and Smith, C.T. 2011. Drivers for renewable energy: a comparison among OECD countries. Biomass and Bioenergy, Vol. 35, No. 11, 4497-4503. 
Hagen K. D. Introduction to Renewable Energy for Engineers. 2016. Weber State University. ISBN-13: 9780133360868.

Heal G. 2010. Reflections - The Economics of Renewable Energy in the United States // Review of Environmental Economics and Policy, Winter. Vol. 4. 1.139-154.

International Energy Agency. 2015. Energy and Climate Change. IEA Publications. Paris: Cedex. P. 446. ISSN: 2074-3974. https://www.iea.org/publications/freepublications / publication/WEO2015 Special Reporton Energyand Change.pdf

John S. Sustainable Biomass: A Systems View. 2004. USDOE/NASULGC Biomass and Solar Energy Workshops

John S. Sustainable Biomass: A Systems View. 2004. USDOE/NASULGC Biomass and Solar Energy Workshops

Law of Energy No. IX-884. 2002. https://e-seimas.lrs.lt/portal/legalAct/lt/TAD/TAIS.167899

Lietuvos Respublikos atsinaujinančiu išteklių energetikos įstatymas. Lietuvos Respublikos Seimas, $2011 \mathrm{~m}$. gegužès 12 d. Nr. XI-1375. https://www.e-tar.lt/portal/lt/legal Act/TAR.FC7 AB69BE291 $/ \mathrm{pPk}$ MV Hzker

Lund H. Renewable Energy Systems: The Choice and Modeling of 100\% Renewable Solutions. Amsterdam, Boston (Mass.): Elsevier. 2010. P. 275. ISSN 2283-9216.

Lund H. Renewable Energy Systems: The Choice and Modeling of 100\% Renewable Solutions. Amsterdam, Boston (Mass.): Elsevier. 2010, 275. ISSN 2283-9216.

Ma L., Li Z., Fu F., Zhang X., Ni W. 2009. Alternative energy development strategies for China towards 2030. Frinties of Energy and Power Engineering in China, Vol. 3. No. 1, 2-10. ISSN 1673-7393.

Maradin, D., Cerović, L., Mjeda, T. 2017. Economic Effects of Renewable Energy Technologies. Our economy, Vol. 63, no. 2, 49-59.

Marčiukaitis M., Dzenajavičienè E. F, Kveselis V., Savickas J., Perednis E., Lisauskas A., Markevičius A., Marcinauskas K., Gecevičius G., Erlickytè-Marčiukaitienè R. Atsinaujinančiu energijos išteklių naudojimo Lietuvoje patirtis, reikšmè ir siekiai. Energetika. 2016. T. 62. Nr. 4. P. 247-267. ISSN 0235-7208.

Miškinis V., Galinis A., Konstantinavičiūtè I., Lekavičius V. 2014. Energijos vartojimo Lietuvoje ir ES šalyse tendencijos. Energetika, T.60. Nr.2, P. 96-112.

Oguz, O., Aslan, A. 2013. Renewable energy consumption-economic growth nexus in Turkey. Renewable and Sustainable Energy Reviews, Vol. 28, 494-499.

REY (Renewable Energy Yearbook). 2016. http://www.taastuvenergeetika.ee/wp-content/ uploads/ 2017/08 / Renewable-energy-yearbook_2016.pdf

Soava, G., Mehedintu, A., Sterpu, M., Raduteanu, M. (2018). Impact of renewable energy consumption on economic growth: evidence from European Union countries. Technological and Economic Development of Economy, Vol. 24, 3, 914-932. ISSN 2029-4913

Štreimikienė D. Wadim A. Strielkowski B, Bilan Y. C, Mikalauskas I. 2016. Energy dependency and sustainable regional development in the Baltic States - a review. Geographica Pannonica, Vol.20, Issue 2, 79-87.

Wooldridge, J. M. (2010). Econometric Analysis of Cross Section and Panel Data. The MIT Press Cambridge, Massachusetts London, England. http://www.ipc-undp.org /evaluation /apoio / Wooldridge $\% 20-\% 20$ Cross-section $\% 20$ and $\% 20$ Panel $\% 20$ Data.pdf 